УДК 347.422

DOI https: / / doi.org/10.32837 / yuv.v0i1.1564

\author{
М. Габріадзе, \\ кандидат юридичних наук, \\ доцент кафедри конституційного, міжнародного та приватного права \\ Криворізького факультету \\ Національного університету «Одеська юридична академія»
}

\title{
СИСТЕМА ЦИВІЛЬНО-ПРАВОВОЇ ВІДПОВІДАЛЬНОСТІ ЗА ПОРУШЕННЯ ЗОБОВ'ЯЗАННЯ
}

Цивільно-правова відповідальність це правова конструкція, що є базисом режиму законності й правопорядку, забезпечує ефективне виконання особою своїх зобов'язань. Соціальна сутність відповідальності виявляється в розумінні, усвідомленні та розмежуванні наслідків діяльності за критеріями їі правомірності й доцільності, можливості осуду або заохочення.

Так чи інакше, становлення окремих елементів системи цивільно-правової відповідальності залежить від аналітичних можливостей і навіть мистецтва передбачати наслідки діяльності особи й оцінювати їх відповідно до чинної системи правових цінностей.

Дискусія про поняття й систему цивільно-правової відповідальності не припиняється в юридичній науці. I сьогодні не існує єдиного доктринального визначення цього терміна. Уважаємо, що сучасна українська цивілістика потребує грунтовного дослідження системи цивільно-правової відповідальності у сфері порушення зобов'язань.

Серед теоретичних розробок у сфері цивільно-правової відповідальності варто виділити праці В.А. Ойгензихта, М.С. Малєіна, О.С. Іоффе, О.О. Красавчикова, І.С. Канзафарової, Н.С. Кузнєцової, О.В. Дзери, М.В. Сибільова, Р.Б. Шишки, Є.О. Харитонова В.І. Борисової, В.В. Луць та ін. Базовими в дослідженні стали праці H.I. Дуравкіної «Відповідальність як складова механізму забезпечення прав і свобод людини й громадянина» [1], Р.Ю. Заіки «Юридична природа цивільно-правової відповідальності без вини» [2], Р.Б. Шишки «Цивільно-правова відповідальність і деліктне зобов'язання» [3], В.В. Паришкури «Проблемні аспекти цивільно-правової відповідальності без вини» [4]. Проте відсутність доктринального дослідження, присвяченого питанням системи цивільно-правової відповідальності за невиконання чи неналежне виконання зобов'язань, зумовлює його актуальність.

Мета статті - з'ясувати особливості системи цивільно-правової відповідальності за порушення зобов'язання, класифікувати ії підстави, розробити пропозиції з удосконалення законодавства, яке регламентує зазначений вид відповідальності.

У цивільно-правовій літературі домінуючою $є$ точка зору, згідно $з$ якою цивільно-правова відповідальність, яка настає за порушення зобов'язань, становить систему обмежень і позбавлень матеріального, особистого та іншого характеру [5, с. 18]. Договірну ж відповідальністю визначають як відповідальність, що виникає в разі невиконання й неналежного виконання зобов'язання, що виникло з договору. Вона настає у випадках, передбачених не тільки законом, а й сторонами в договорі [6, с. 628]. При цьому вважається, що договірна відповідальність окремого зобов'язання не породжує й реалізується шляхом приєднання до вже чинного між сторонами зобов'язання додаткових зобов'язань правопорушника [7, с. 95]. 


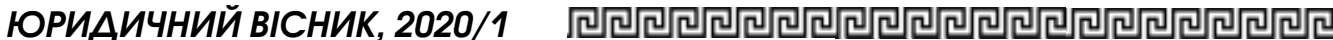

Аналізуючи досвід іноземних держав, варто зазначити, що, наприклад, у цивільному праві Німеччини термін «відповідальність» має різні варіації. Так, для іiі позначення використовуються Verantwortung, Haftpflicht, Verantwortlichkeit, Haftung, але з аналізу німецької наукової доктрини й цивільного законодавства можна зробити висновок, що найбільш еквівалентним для нашого терміна «відповідальність» $€$ Haftung. Цей термін може в одному контексті зводитися до обов'язку нести відповідальність за свої дії, а в іншому до обов'язку з відшкодування шкоди.

При цьому важливо також розмежування понять «відповідальність» (Haftung) та «обов'язок» (Verpflichtung), що виникли на підставі судового рішення. Обов'язок пов'язаний 3 особою (боржником), а відповідальність із його майном $[8$, с. 110-111]. Отже, відповідальність за порушення договірних зобов'язань у німецькому праві полягає в обов'язку особи відшкодувати в грошовій формі матеріальну шкоду, заподіяну невиконанням зобов'язання. Отже, цивільно-правова санкція за невиконання договору має виключно майновий характер.

Отже, проаналізувавши всі наукові підходи, можемо констатувати, що відповідальність за порушення зобов'язання в цивільному праві можна визначити як застосування до особи, котра не виконала або неналежним чином виконала умови договору й/або порушила норми цивільного законодавства, що регулюють зазначені правовідносини, заходів негативного характеру, коли сторона-порушник несе певні майнові обмеження, установлені в договорі або в законі, а потерпіла сторона отримуе відшкодування шкоди та відновлення порушених прав.

Зазначене визначення цивільно-правової відповідальності за порушення зобов'язання може бути використане як базове для визначення окремих іiі видів, адже в межах загальної категорії цивільно-правової відповідальності за невиконання й неналежне виконання зобов'язань існує кілька ії видів. При цьому класифікація здійснюється за різними критеріями. Так, залежно від виду порушення зобов'язання відповідальність можна поділити на відповідальність за невиконання й відповідальність за неналежне виконання зобов'язань. У першому випадку правопорушення здійснюється у формі протиправної бездіяльності; у другому у формі протиправної дії.

Дослідження практики вирішення спорів про неналежне виконання договірних зобов'язань з'ясовує, що часто неналежне виконання договору пов'язано з порушенням вимог про предмет i строк виконання договору. Також в окремих випадках має місце виконання зобов'язання неналежною особою або 3 простроченням виконання договору.

Наслідки прострочення боржника передбачені ст. 612, кредитора ст. 613 Цивільного кодексу (далі ЦК) України. Відповідно до ст. 612, боржник, що прострочив виконання зобов'язання, несе відповідальність перед кредитором за збитки, заподіяні простроченням. Якщо внаслідок прострочення виконання зобов'язання втратило інтерес для кредитора, він має право відмовитися прийняти його й вимагати відшкодування збитків. Боржник не вважається таким, що прострочив, якщо він не може виконати зобов'язання внаслідок прострочення кредитора. У свою чергу, кредитор уважається таким, що прострочив, якщо він відмовляється прийняти виконання, запропоноване боржником, або не вчинив дій, до вчинення яких боржник не міг виконати свого обов'язку. Кредитор також уважається таким, що прострочив, у разі його відмови повернути борговий документ або видати розписку боржникові (ч. 4 ст. 545 ЦК України) [9].

Залежно від перерозподілу відповідальності між кількома боржниками в зобов'язаннях із множиною осіб виокремлюють часткову й солідарну 
відповідальність; основну й субсидіарну (додаткову).

Частковою в цивільно-правовій доктрині визнається відповідальність, яка покладається на двох або більше боржників, кожен із яких відповідає за своїми зобов'язаннями в рівних частках, якщо інше не встановлено законом або договором. Солідарна відповідальність у зобов'язанні - це відповідальність кількох боржників перед кредитором, при цьому кредитору надається право вимагати виконання зобов'язання в повному обсязі або частково від усіх боржників разом чи від кожного окремо.

Досліджуючи солідарну відповідальність, необхідно детально дослідити зміст основної й додаткової (субсидіарної) відповідальності. Основною відповідальністю в цивільно-правовій науці визнається відповідальність боржника, що виникає на підставі норм цивільного законодавства за порушення цивільних зобов'язань. Однак для підвищення якості захисту інтересів учасників зобов'язання іноді застосовується додаткова (субсидіарна) відповідальність. Особливістю субсидіарної відповідальності є таке:

- настає виключно у випадках, передбачених законом або договором;

- є формою додаткової відповідальності, що передбачає наявність основної відповідальності, яку несе боржник;

- покладається на осіб, які не несуть основної відповідальності перед кредитором;

- не може перевищувати розміру основної відповідальності;

- субсидіарно відповідальна особа, яка виконала свої зобов'язання, має право регресної вимоги до основного боржника;

- може бути обмежена законом або пов'язана законом із настанням певних умов.

Наступним критерієм $є$ розмежування повної й обмеженої відповідальності.

За загальним правилом, відповідальність настає в повному обсязі, проте за окремими видами зобов'язань може бути встановлена обмежена відповідальність за їх невиконання або за неналежне виконання. Прикладом обмеження відповідальності боржника може бути зменшення обсягу відповідальності, якщо невиконання або неналежне виконання зобов'язання сталося не тільки з вини боржника, а й із вини кредитора.

На окрему увагу заслуговують такі види відповідальності, як відповідальність за власні дії та відповідальність за дії інших осіб. У передбачених законом випадках за невиконання або неналежне виконання зобов'язання однією особою заходи цивільно-правової майнової відповідальності можуть бути застосовані щодо іншої. У ЦК України відсутня норма такого змісту, проте в ст. 528, що регулює виконання обов'язку третьою особою, міститься положення, що в разі невиконання або неналежного виконання обов'язку боржника іншою особою цей обов'язок боржник повинен виконати сам. Така позиція відображена й у цивілістичній науці, де відповідальність за дії третьої особи розглядається як випадок відповідальності за виконання зобов'язань без вини. На думку автора, розмежування відповідальності за власні дії й за дії іншої особи, на яку покладене виконання зобов'язання, видається цілком обгрунтованим. Деякі випадки такого покладання відповідальності передбачені законом. Наприклад, ст. 240 ЦК передбачає, що представник зобов'язаний учиняти правочин за наданими йому повноваженнями особисто, проте він може передати свої повноваження частково або в повному обсязі іншій особі.

Третім і найбільш значимим сегментом наукового дослідження, окрім дефініції та критеріїв класифікації, стане дослідження системи цивільно-правової відповідальності за порушення зобов'язань.

Будь-яка система - це сукупність елементів, що знаходяться в певній єдності й перманентній взаємодії між собою. Складниками системи права 


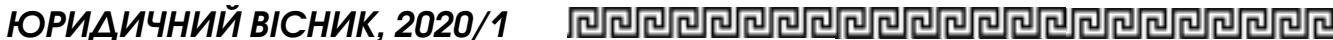

(правової системи) є, як відомо, галузі права, підгалузі права, правові інститути та правові норми. Усі зазначені елементи системи відрізняються насамперед за кількістю правових норм і колом суспільних відносин, урегульованих цими нормами. Відповідно, і складники системи цивільно-правової відповідальності як галузевого правового інституту також складаються 3 правових норм [10, с. 28].

Під час дослідження цивільно-правової відповідальності як функціональної системи вельми важливим є аналіз ii структурних елементів. Для цього необхідно, по-перше, визначити критерій, що диференціює юридичну відповідальність на види (структурні елементи), по-друге, показати не тільки особливості кожного структурного елементу, а й відповідність специфічним особливостям структури функціональної системи загалом і системи цивільної відповідальності зокрема. До основних елементів систем юридичної відповідальності загалом і цивільно-правової відповідальності за порушення зобов'язань зокрема належать мета, умови, функціі, форми та підстави відповідальності [11].

Мета застосування заходів відповідальності за порушення зобов'язань - формування правомірної поведінки суб'єктів зобов'язального права як осіб, що порушили зобов'язання, так і всіх інших членів суспільства, захист позитивного договірного інтересу, компенсація втрат потерпілої сторони для відновлення майнового стану, який існував до укладення договору. Окрім цього, відповідальність за порушення зобов'язань як одна 3 форм юридичної відповідальності має на меті захист прав людини й підтримання правопорядку; виховання суб'єкта в дусі поваги до права; відновлення соціальної справедливості; запобігання вчиненню нових правопорушень.

Досягнення мети відповідальності за порушення зобов'язань $є$ результатом реалізації функцій цивільно-правової відповідальності. До них належать:
1) охоронна - полягає в захисті правопорядку. Юридична відповідальність за порушення зобов'язань $€$ мірою захисту особи від неправомірних соціально шкідливих діянь, адже зумовлює обов'язок правопорушника зазнати певних обмежень свої прав як покарання за невиконання чи неналежне виконання зобов'язань. У цьому - соціальна справедливість юридичної відповідальності;

2) правовідновна (компенсаційна) полягає в поновленні порушеного права. Ця мета особливо характерна для цивільно-правової відповідальності за невиконання чи неналежне виконання зобов'язань. Вона полягає в обов'язку відшкодувати завдану матеріальну й моральну шкоду;

3) превентивна - полягає в запобіганні вчиненню нових порушень зобов'язальних умов (превенція). Юридична відповідальність покликана, з одного боку, обмежити можливості правопорушника вчинити нове правопорушення, 3 іншого - запобігти правопорушенням інших зобов'язань;

4) виховна - юридична відповідальність виховує повагу до прав і законних інтересів інших осіб-учасників зобов'язання. Застосування заходів цивільно-правової відповідальності має сприяти виправленню та перевихованню правопорушника. У його свідомості й поведінці мають сформуватися та закріпитися поважне ставлення до права й закону, прав, свобод і законних інтересів суб'єктів зобов'язання.

Цивільно-правова відповідальність $є$ негативним для порушника наслідком порушеного зобов'язання. Юридичною підставою такої відповідальності є закон, а фактичною - склад цивільного правопорушення. До його складу входять такі елементи: факт порушення умов зобов'язання, заподіяння шкоди, причинно-наслідковий зв'язок між ними й вина особи. Першим елементом є протиправна поведінка боржника, яка полягає в порушенні зобов'язання.

Виділяються дві форми порушення зобов'язання. Зобов'язання може бути 
порушено у формі бездіяльності, яка полягає в невиконанні зобов'язання. У цьому разі з боку боржника відсутні діï, які відповідають умісту зобов'язання. Також зобов'язання може бути порушено у формі дії, що полягає в неналежному виконанні зобов'язання. У цьому разі боржник здійснив певні дії на виконання зобов'язання, але вони не відповідають установленим законом і договором вимогам щодо належного виконання зобов'язання.

Важливою умовою настання цивільно-правової відповідальності $€$ протиправність дій особи, що порушила умови зобов'язання. Високий рівень правосвідомості людей, які творять норми права, дає змогу досить чітко визначити межу між допустимим обмеженням прав суб'єктів громадянського суспільства й неприпустимим обмеженням зазначених прав. Отже, видається, що неправомірна поведінка - це дія (або бездіяльність), що перевищує встановлені правом норми поведінки суб'єкта цивільно-правових відносин.

Отже, ми підходимо до поняття протиправності. Суб'єкти цивільно-правових відносин намагаються здійснювати свою діяльність так, щоб не порушувати законодавство України, охоронювані законом права та інтереси інших осіб. Однак перманентна загроза відповідальності може суттєво знизити підприємницьку ініціативу учасників цивільного обороту. Щоб запобігти цьому потрібно створити умови, за яких у суб'єктів цивільно-правового зобов'язання виникала обгрунтована впевненість у тому, що вони не будуть нести відповідальність за непрогнозовані наслідки їхньоі діяльності, тому що, за загальним правилом, цивільно-правова відповідальність базується на засадах вини.

Другим елементом правопорушення $€$ негативні наслідки у формі збитків. Проте щодо зазначеного терміна не існує єдиної доктринальної позиції. Згідно з позицією В.В. Вітрянського, поняття «збитки» необхідно відрізняти від категорій «шкода» і «збитки», котрі зазвичай уживаються для позначення однієі з умов цивільно-правової відповідальності або одного 3 елементів складу цивільного правопорушення [6, с. 642]. Однак варто зауважити, що в науковій літературі такого чіткого розмежування зазначених правових категорій не здійснено. Законодавець виділяє в складі збитків реальні збитки та упущену вигоду [9].

Реальні збитки - це фактичні витрати особи, які можна розділити на два види: витрати, необхідні для відновлення порушеного права, і вартість утраченого або пошкодженого майна. Під упущеною вигодою розуміються не отримані доходи, тобто сума, на яку могли б збільшитися активи особи, право якої порушено, якби зобов'язання було виконано належним чином.

Останнім, проте найбільш вагомим елементом системи цивільно-правової відповідальності за порушення зобов'язання є форма відповідальності. Так, популярною в цивілістичній науковій літературі є позиція, згідно з якою відповідальність за порушення договірних зобов'язань реалізується у двох формах: у формі неустойки, а також у формі стягнення збитків.

Однак аналіз наукових досліджень у сфері цивільно-правової відповідальності дає змогу зробити висновок про існування двох основних форм відповідальності, на їх основі формується третя форма - комбінована. Перша базова форма полягає в зобов'язанні винної особи здійснити передачу майна, сплату грошей тощо. Характерними рисами такого виду відповідальності $€$ те, що вона $є$ факультативним обтяженням і має безеквівалентний характер. Друга базова форма полягає в позбавленні особи прав, що їй належать. Змішана форма містить елементи двох перших базових форм.

Проте більш вдалим, на думку автора, видається розподіл форм відповідальності на загальні й спеціальні. Загальною формою відповідальності за невиконання або неналежне виконання зобов'язань $є$ обов'язок боржника від- 


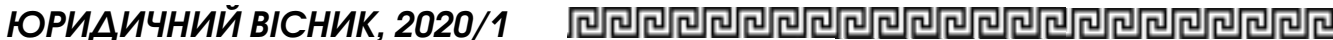

шкодувати збитки, заподіяні порушенням зобов'язання, кредитору. Зазначена форма цивільно-правової відповідальності застосовується в разі невиконання будь-якого зобов'язання, унаслідок чого вона й розглядається як універсальна категорія. Однак основною умовою притягнення особи до цивільно-правової відповідальності у формі відшкодування збитків є наявність зазначених збитків. Якщо ж збитків немає, потрібні спеціальні форми відповідальності за порушення зобов'язань, до яких належать стягнення неустойки: штрафу або пені, відмова від повернення завдатку та різні санкції, що застосовуються до окремих видів зобов'язань. Варто зазначити, що, оскільки стягнення збитків, які виникли внаслідок невиконання чи неналежного виконання зобов'язання, $€$ загальною формою відповідальності, навіть якщо сторони в договорі не передбачили такий захід відповідальності, застосування його $€$ доцільним та обгрунтованим.

Що стосується спеціальних форм відповідальності, то до них варто зарахувати відповідальність за прострочення виконання грошового зобов'язання, передбачену ст. 625 ЦК України: на боржника покладається обов'язок сплатити кредитору суму заборгованості 3 урахуванням установленого індексу інфляції, а також три проценти річних від простроченої суми, якщо інший розмір процентів не встановлено договором або законом.

Проценти, що стягуються за прострочення виконання грошового зобов'язання, є санкцією за його порушення. Отже, на відміну від процентів, які $€$ звичайною платою за користування грошима, зокрема, за договором позики (ст. 1048 ЦК України), до них застосовуються загальні норми про цивільно-правову відповідальність. Проценти, установлені ст. 625 ЦК України, підлягають стягненню за наявності протиправного невиконання (неналежного виконання) грошового зобов'язання [9].

Підводячи підсумки дослідження, можна зробити такі висновки: 1. Склад- ність юридичної природи цивільно-правової відповідальності за порушення зобов'язання зумовила множинність підходів до їі розуміння й інтерпретації ii у вітчизняній науці цивільного права: а) як заходу державного примусу; б) як санкції за неправомірну поведінку; в) як обов'язку правопорушника відшкодувати завдані збитки і сплатити неустойку; г) як захід покарання за вчинене правопорушення. 2. Існує низка критеріїв класифікації цивільно-правової відповідальності за порушення зобов'язання. Зокрема, залежно від перерозподілу відповідальності між кількома боржниками в зобов'язаннях із множиною осіб виокремлюють часткову й солідарну відповідальність; основну й субсидіарну (додаткову). 3. Юридичною підставою настання цивільно-правової відповідальності за договором $є$ склад цивільного правопорушення, який утворюють правопорушення, заподіяння шкоди, причинно-наслідковий зв'язок між ними й вина. 3. До основних елементів систем юридичної відповідальності загалом і цивільно-правової відповідальності за порушення зобов'язань зокрема належать мета, умови, функції, форми та підстави відповідальності.

Стаття присвячена дослідженню иивільно-правової відповідальності як одного з наслідків порушення зобов'язання, структурних елементів цивільно-правової відповідальності, ї ролі в механізмі забезпечення наленного виконання зобов'язань i захисту иивільних прав та інтересів у сучасному иивільному праві України. Залежно від виду порушення зобов'язання відповідальність можна поділити на відповідальність за невиконання й відповідальність за неналежне виконання зобов'язань. Мета статті - визначити особливості системи цивільно-правової відповідальності за порушення зобов'язання, класифікувати ї підстави, розробити пропозиції з удосконалення законодавства, яке 
регламентуе зазначений вид відповідальності. Цивільно-правова відповідальність - це правова конструкція, що є базисом режиму законності й правопорядку, забезпечує ефективне виконання особою своїх зобов'язань. Соціальна сутність відповідальності виявляється в розумінні, усвідомленні та розмежуванні наслідків діяльності за критеріями ї̈ правомірності й доиільності, можливості осуду або заохочення. Складність юридичної природи цчивільно-правової відповідальності за порушення зобов'язання зумовила множинність підходів до ї̈ розуміння й інтерпретаціï $y$ вітчизняній науиі ицвільного права: а) як заходу державного примусу; б) як санкиіï за неправомірну поведінку; в) як обов'язку правопорушника відикодувати завдані збитки i сплатити неустойку; г) як захід покарання за вчинене правопорушення. Констатовано, що існуе низка критеріїв класифікації цивільно-правової відповідальності за порушення зобов'язання. Відзначено, щзо юридичною підставою настання цивільно-правової відповідальності за договором є склад изивільного правопорушення, який утворюють правопорушення, заподіяння шкоди, причинно-наслідковий зв'язок між ними й вина. З'ясовано структурні елементи изивільно-правової відповідальності, ї̈ роль у механізмі забезпечення наленного виконання зобов'язань i захисту иивільних прав та інтересів у сучасному цивільному праві України. Окреслено, що до основних елементів систем юридичної відповідальності загалом $і$ иивільно-правової відповідальності за порушення зобов'язань зокрема належать мета, умови, функиіі, форми та підстави відповідальності.

Ключові слова: система цивільно-правової відповідальності, порушення зобов'язань, захист порушених прав та інтересів, боржник, кредитор, збитки, засоби забезпечення виконання зобов'язань.
Habriadze M. System of civil liability for breach of obligations

The article deals with the study of civil liability as one of the consequences of breach of obligations, structural elements of civil liability, its role in the mechanism of ensuring the proper fulfillment of obligations and protection of civil rights and interests in modern civil law of Ukraine. Depending on the type of breach of liability, liability can be divided into liability for default and liability for improper fulfillment of obligations. The purpose of the article was to identify the peculiarities of the system of civil liability for breach of obligations, to classify its grounds and to develop suggestions for improvement of the legislation regulating the specified type of liability. Civil liability is a legal framework that underlies the rule of law and order and ensures the effective fulfillment of a person's obligations. The social essence of responsibility is manifested in the understanding, awareness and differentiation of the consequences of activity by the criteria of its legitimacy and expediency, the possibility of condemnation or encouragement. The complexity of the legal nature of civil liability for breach of the obligations led to a multiplicity of approaches to its understanding and interpretation in the domestic science of civil law: a) as measures of state coercion; b) as sanctions for misconduct; $c$ ) as the offender's obligations to reimburse for the damage caused and to pay the penalty; d) as a punishment for the offense. It is stated that there are a number of criteria for the classification of civil liability for breach of obligations. The article is devoted to the study of civil liability as one of the consequences of breach of obligations, structural elements of civil liability, its role in the mechanism of ensuring the proper fulfillment of obligations and protection of civil rights and interests in modern civil law of Ukraine. It is noted that the legal basis for the onset of civil liability under the contract is the 


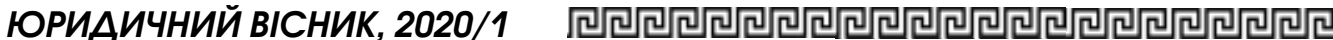

composition of the civil offense, which is formed by: the offense, causing harm, causation between them and the fault. It is outlined that the main elements of the systems of legal liability as a whole and civil liability for breach of obligations include, in particular, the purpose, conditions, functions, forms and grounds of liability.

Key words: system of civil liability, breach of obligations, protection of violated rights and interests, god, creditor, damages, means of ensuring fulfillment of obligations.

\section{Література}

1. Дуравкіна H.I. Відповідальність як складова механізму забезпечення прав $i$ свобод людини й громадянина. Юридична наука і практика. 2011. № 2. С. 15-21.

2. Заіка Р.Ю. Юридична природа цивільно-правової відповідальності без вини. Юридична наука. 2014. № 5. С. 7-14.

3. Шишка Р.Б. Цивільно-правова відповідальність $i$ деліктне зобов'язання. Збірник наукових праць Ірпінської фінансово-юридичної академії. Серія «Право». 2013. Bun. 2. C. 206-216.
4. Паришкура В.В. Проблемні аспекти иивільно-правової відповідальності без вини. Вісник Вищої ради юстищіі. 2010. № 2. C. $66-74$.

5. Шиндяпина М.Д. Стадии юридической ответственности. Москва : Книжный мир, 1998. 162 с.

6. Брагинский М.И., Витрянский В.В. Договорное право. Москва: Статут, 2011. Книга первая: Общие положения. 847 с.

7. Иофре О.С. Обязательственное право. Избранные труды. Санкт-Петербург : Пресс, 2004. T. III. 837 c.

8. Thur A., von. Der Allgemeine Teil des deutschen Bbrgerlichen Rechtsin 2 B. Leipzig: Verlag von Duncker \& Humblot, 1910. B 1 : Allgemeine Lehren und Personenrecht.

9. Цивільнии кодекс України від 16.01.2003 № 435-IV. URL: https:// zakon.rada.gov.ua/laws / show /435-15/ ed20060220 / stru (дата звернення: 17.03.2020).

10. John Henry Merryman \& Rogelio Pürez-Perdomo. The Civil Law Tradition: An Introduction to the Legal Systems of Europe and Latin America, 4th edn. Stanford University Press, 2018. P. 192.

11. Deborah C. England. Civil Liability. URL: https: / / www.criminaldefenselawyer. $\mathrm{com} / \mathrm{resources} /$ civil-liability.htm (dama звернення: 17.03.2020). 